\title{
The advertisement call of two species of the Rhinella granulosa group (Anura: Bufonidae)
}

\author{
Ariovaldo Antonio Giaretta, ${ }^{1}$ Isabelle Aquemi Haga, ${ }^{1}$ and Felipe Silva de Andrade ${ }^{1,2}$ \\ ${ }^{1}$ Laboratório de Taxonomia e Sistemática de Anuros Neotropicais (LTSAN), Instituto de Ciências Exatas e Naturais do Pontal \\ (ICENP), Universidade Federal de Uberlândia (UFU). Ituiutaba, MG, Brazil. E-mail: aagiaretta@gmail.com. \\ ${ }^{2}$ Laboratório de História Natural de Anfíbios Brasileiros (LaHNAB), Departamento de Biologia Animal, Instituto de Biologia, \\ Universidade Estadual de Campinas (UNICAMP). Campinas, SP, Brazil.
}

\begin{abstract}
The advertisement call of two species of the Rhinella granulosa group (Anura: Bufonidae). The group of Rhinella granulosa presently harbors 14 species distributed in Central and South America. The advertisement calls of 12 species have been described. Herein, we provide data on the calls of $R$. granulosa and $R$. merianae recorded in populations far from locations of previous call descriptions, and we discuss possible causes of differences found. We used recordings of $R$. granulosa from the interior of Bahia State and recordings of $R$. merianae from Roraima. For both, calls consist of a long-lasting trill of four-pulsed notes. Rhinella granulosa calls last 3.7-9.6 s, have 121-283 notes, each lasting 19-25 ms released at a rate of 29.2-34.7/s, and with dominant frequency peaking between 2472-2809 Hz. Rhinella merianae calls last 4.0-7.1, have 153-217 notes, each lasting $17-20 \mathrm{~ms}$, released at a rate of $37.7-39.5 / \mathrm{s}$, and with dominant frequency peaking between 2959-3189 Hz. Both species are distinguished from most other species of the $R$. granulosa species group by the combination of pulse number and dominant frequency. Our data on $R$. granulosa differed $(p<0.05)$ in call duration and/or in dominant frequency from specimens from Natal (Rio Grande do Norte state) and Cabaceiras (Paraíba state). Our data on $R$. merianae appear to differ in dominant frequency from the only call (a single male) known from the Amazon River bank. The differences we found between our data and published call data suggest that further study of calls of additional populations of these species is warranted.
\end{abstract}

Keywords: Lissamphibia, bioacoustics, South American toads, taxonomy.

\section{Resumo}

O canto de anúncio de duas espécies do grupo de Rhinella granulosa (Anura: Bufonidae). O grupo de Rhinella granulosa atualmente abriga 14 espécies distribuídas nas Américas Central e do Sul, sendo conhecido o canto de anúncio de 12 delas. Descrevemos novos dados acústicos de $R$. granulosa e $R$. merianae oriundos de populações distantes daquelas com dados conhecidos e

Received 18 October 2018

Accepted 05 December 2018

Distributed December 2018 
discutimos possíveis causas das diferenças encontradas. As gravações de $R$. granulosa são do interior do estado da Bahia e as de $R$. merianae, do estado de Roraima. Para ambas as espécies, o canto consiste em um trinado de longa duração de notas com quatro pulsos. O canto de $R$. granulosa tem duração de 3,7-9,6 s e 121-283 notas, tendo cada nota a duração de 19-25 ms, emitidas a uma taxa de $29,2-34,7 / \mathrm{s}$, com seus picos de frequência dominante entre 2472 e $2809 \mathrm{~Hz}$. O canto de $R$. merianae dura de 4,0-7,1 s, possui 153-217 notas, tendo cada nota a duração de 17-20 ms, emitidas a uma taxa de 37,7-39,5/s; os picos de frequência dominante das notas estão entre 2959 e $3189 \mathrm{~Hz}$. Ambas as espécies podem ser diferenciadas da maioria das outras espécies do grupo pela combinação de número de pulsos e frequência dominante. Os dados de $R$. granulosa apresentados aqui diferiram $(p<0,05)$ na duração do canto e/ou frequência dominante dos dados conhecidos de espécimes de Natal (estado do Rio Grande do Norte) e Cabaceiras (estado da Paraíba). Nossos dados de $R$. merianae parecem diferir em frequência dominante dos dados de um único macho reportado da margem do Rio Amazonas. As diferenças acústicas encontradas encorajam futuras investigações taxonômicas que utilizem uma abordagem integrativa para ambas as espécies.

Palavras-chave: Lissamphibia, bioacústica, sapos sulamericanos, taxonomia.

\section{Introduction}

Rhinella Fitzinger, 1826 is an exclusively Neotropical true-toad (Bufonidae) taxon. The Rhinella granulosa group currently is comprised of 14 species distributed from Central America (Panamá) to southern South America (Argentina and Uruguay) (Narvaes and Rodrigues 2009, Murphy et al. 2017). A major taxonomic review based on morphology/morphometry was conducted by Narvaes and Rodrigues (2009) and later complemented by Murphy et. al. (2017). Pereyra et al. (2015) provided a molecular phylogeny and discussed hybridization and introgression in this clade. So far, the advertisement calls of 12 species of the $R$. granulosa group have been described: $R$. azarai (Gallardo, 1965), Rhinella beebei (Gallardo, 1965), R. bergi (Céspedez, 2000), R. centralis Narvaes and Rodrigues, 2009, $R$. dorbignyi (Duméril and Bibron, 1841), R. fernandezae (Gallardo, 1957), R. granulosa (Spix, 1824), $R$. humboldti (Gallardo, 1965), R. major (Müller and Hellmich, 1936), R. mirandaribeiroi (Gallardo, 1965), R. pygmaea (Myers and Carvalho, 1952), and $R$. merianae (Gallardo, 1965) (Zweifel 1965, Köhler et al. 1997, Salas et al. 1998, Guerra et al. 2011, São-Pedro et al. 2011, Morais et al. 2012, Torres-Suárez and Vargas-Salinas 2013,
Carvalho et al. 2013, Protázio et al. 2015, Bernardes et al. 2015, Murphy et al. 2017). Calls are unknown for $R$. nattereri (Bokermann, 1967) and R. bernardoi (Sanabria, Quiroga, Arias, and Cortez, 2010).

Rhinella granulosa was described from the Brazilian state of Bahia and is thought to have a broad distribution across northeast Brazil (states of Bahia, Sergipe, Alagoas, Pernambuco, Paraíba, Rio Grande do Norte, Ceará, and Piauí) and northern states of southeastern Brazil (Minas Gerais and Espírito Santo) (Narvaes and Rodrigues 2009). Its call is known from specimens from Rio Grande do Norte (SãoPedro et al. 2011) and Paraíba (Protázio et al. 2015). Rhinella merianae was described from Essequibo River, Guiana and is known to occur in Venezuela, French Guiana, Suriname, and along the Solimões, Negro and Branco Rivers in the Brazilian states of Amazonas and Roraima (Narvaes and Rodrigues 2009). Its call is known from a male recorded at the margins of the Amazon River in central Amazonia (Guerra et al. 2011).

Herein we present data on the advertisement calls of $R$. granulosa and $R$. merianae recorded in populations distant from previous call descriptions. We found significant differences in these advertisement calls compared to original 
descriptions attributed to these species, and we discuss the likely causes for such discrepancies.

\section{Materials and Methods}

Calls were recorded using Marantz digital recorders (PMD 670 and PMD 671) set at sampling rates of 44.1 or $48 \mathrm{kHz}$ and 16-bit resolution, coupled to Sennheiser ME67/K6 or ME66/K6 directional microphones. Our recordings of $R$. granulosa are from Andaraí (12 ${ }^{\circ} 48^{\prime} 13.85^{\prime \prime} \mathrm{S}, 41^{\circ} 19^{\prime} 52.14^{\prime \prime} \mathrm{W}, 403 \mathrm{~m}$ a.s.1.), Caetité $\left(14^{\circ} 03^{\prime} 53.56^{\prime \prime} \mathrm{S}, 42^{\circ} 28^{\prime} 3.03^{\prime \prime} \mathrm{W}, 793 \mathrm{~m}\right.$ a.s.l.), and Xique-Xique (10 51'09.07" S, $42^{\circ} 38^{\prime} 06.63 " \mathrm{~W}, 457 \mathrm{~m}$ a.s.1.), all municipalities in the interior state of Bahia. Because preliminary call analyses did not indicate major differences among these three populations (results not shown) and voucher specimens fit well with the diagnosis of Narvaes and Rodrigues (2009), samples were pooled for further analyses. Males of $R$. merianae were recorded at a site (02 ${ }^{\circ} 45^{\prime} 30.84^{\prime \prime} \mathrm{N}, 60^{\circ} 36^{\prime} 18.94 " \mathrm{~W}, 76 \mathrm{~m}$ a.s.1.) along the highway BR 432, municipality of Cantá, state of Roraima. Voucher specimens are in the frog collection at Museu de Biodiversidade do Cerrado, Universidade Federal de Uberlândia: $R$. granulosa AAG-UFU 5132-3, $5610,5663-4$, and $R$. merianae AAG-UFU 5546-48, 5556-57. Further details on recordings including dates, time, recorders and microphones are in Appendix I.

Calls were analyzed in Raven Pro 1.5 (Bioacoustics Research Program 2014) with the following settings: window size $=256$ samples, window type $=$ Hann, $3 \mathrm{~dB}$ filter bandwidth $=$ $270 \mathrm{~Hz}$, overlap $=85 \%$ (locked), DFT size $=$ 1024 samples, grid spacing $=43.1 \mathrm{~Hz}$. Calls were filtered up to $400 \mathrm{~Hz}$ to reduce background noise (mostly wind) interference. Figures of calls were generated in Seewave (Sueur et al. 2008) in R 3.4.1 (R Core Team 2018) with 256 points resolution (FFT), Hanning window, and $85 \%$ overlap. Analyzed call definitions followed Köhler et al. (2017) and Raven Pro manual, as follows: call duration, call note number, note duration, note rate, 5 and $95 \%$ frequencies, dominant frequency, note pulse number, first pulse duration, duration of the most energetic pulse, last pulse duration, and note and call intervals.

Significance of the differences of taxonomically relevant call features were tested in $\mathrm{R}$ based on descriptive statistics with the "tt.brief" function of the lessR package (Gerbing 2018) or raw data with the function "Exact Wilcoxon Mann Whitney Rank Sum Test" using the package coin (Resampling Statistics, function "wilcox_ test", Hothorn et al. 2008). As pulse duration varies within notes and authors seldom mentioned what pulses they measured, we avoided performing significance tests on this variable.

\section{Results}

\section{Rhinella granulosa}

Males called from the margins of a manmade pond surrounded by pasture (Caetité) and along the margins of a shallow ( $<1 \mathrm{~m}$ deep), sand-bottomed river crossing the urban area of Andaraí. Male SVL from these areas, including vouchers, are: mean $=49.3, \mathrm{SD}=3.22 \mathrm{~mm}, N=$ 10 . The calls ( $N=12$ males, 41 calls, 821 notes) consist of a long-lasting trill of pulsed notes; maximum amplitude is reached quickly and remains constant to the end. Notes have four concatenated (no silence intervals) pulses (Figure 1); one male released a few notes with five pulses. Calls last from 3.7 to $9.6 \mathrm{~s}$ and have $121-$ 283 notes per call. Notes last $19-25 \mathrm{~ms}$ and are released at a rate of 29.2-34.7/s. Dominant (= fundamental) frequency peaks range from 2472 to $2809 \mathrm{~Hz}$. The most energetic pulses last 5-6 $\mathrm{ms}$ and the inter-note interval is $7-13 \mathrm{~ms}$. Further details can be found in Table 1 .

\section{Rhinella merianae}

Males were recorded while calling along scattered shallow pools $(<30 \mathrm{~cm}$ deep) of an almost empty abandoned fish pool and along 
Table 1. Call features of our samples of Rhinella granulosa from Bahia state (Andaraí, Caetité, and Xique-Xique); and of Rhinella merianae from Roraima state (Cantá), Brazil. $N=$ number of recorded males (analyzed notes). Values are mean $\pm \mathrm{SD}$ (range).

\begin{tabular}{lcc}
\hline Call Features & $\begin{array}{c}\text { Rhinella granulosa (Bahia state) } \\
\mathbf{N}=\mathbf{1 2} \text { males (821) }\end{array}$ & $\begin{array}{c}\text { Rhinella merianae (Roraima state) } \\
\mathbf{N}=\mathbf{5} \text { males (399) }\end{array}$ \\
\hline Call duration (s) & $5.9 \pm 1.7(3.7-9.6)$ & $5.4 \pm 1.1(4.0-7.1)$ \\
Intercall interval (s) & $10.9 \pm 7.5(5.0-25.9)$ & $4.7 \pm 0.5(4.4-5.1)$ \\
Number of notes per call & $187 \pm 49.7(121-283)$ & $193 \pm 29.3(153-217)$ \\
Note duration (ms) & $21 \pm 2(19-25)$ & $19 \pm 1(17-20)$ \\
Internote interval (ms) & $10 \pm 2(7-13)$ & $7 \pm 1(7-8)$ \\
Note rate (notes/second) & $31.8 \pm 2.2(29.2-34.7)$ & $3.8 \pm 0.4(3.0-4.0)$ \\
Pulses per note & $4.1 \pm 0.3(4.0-5.0)$ & $5 \pm 0(5-5)$ \\
First pulse duration (ms) & $5 \pm 1(5-7)$ & $5 \pm 0(5-5)$ \\
Most energetic pulse duration (ms) & $5 \pm 0(5-6)$ & $5 \pm 1(5-6)$ \\
Last pulse duration (ms) & $5 \pm 1(4-7)$ & $2499 \pm 116(2398-2680)$ \\
Frequency $5 \%(\mathrm{~Hz})$ & $2282 \pm 73(2192-2411)$ & $3377 \pm 102(3273-3503)$ \\
Frequency 95\% (Hz) & $3019 \pm 113(2844-3173)$ & $3036 \pm 95(2959-3189)$ \\
Dominant frequency (Hz) & $2640 \pm 112(2472-2809)$ & $39.5)$ \\
\hline
\end{tabular}

shallow pools ( $<10 \mathrm{~cm}$ deep) along a dirt road. The co-occurrence with the Pseudinae aquatic frog Lysapsus laevis (Parker, 1935) suggests long-standing water in the fish pool. Surrounding natural vegetation includes a particular type of Amazonian savanna regionally called "lavrado" (Barbosa et al. 2007, Carvalho and Carvalho 2012); rivers are bordered by narrow riparian forests. SVL of vouchers are: mean $=45.1$, SD $=4.16 \mathrm{~mm}, N=5$. The calls $(N=5$ males, 20 calls, 399 notes) consist of a long-lasting trill of pulsed notes; maximum amplitude is reached quickly and remains constant to the end. Notes have four (rarely 3-4 pulses, $N=$ one male) concatenated pulses (Figure 2). Calls last 4.0-7.1 $\mathrm{s}$ and have 153-217 notes per call. Notes last 17-20 $\mathrm{ms}$ and are released at 37.7-39.5/s. The dominant frequency (= fundamental) peaks are between 2959 and $3189 \mathrm{~Hz}$. The most energetic pulse lasts $5 \mathrm{~ms}$ and the note interval is $7-8 \mathrm{~ms}$. Further details are given in Table 1.

\section{Discussion}

\section{Rhinella granulosa}

The exact type locality of $R$. granulosa is unknown (Frost 2018) and potentially includes areas of the state of Bahia visited by Spix and Martius, which encompasses different environments such as Caatinga and Atlantic Forest (Narvaes and Rodrigues 2009). São-Pedro et al. (2011) described calls from around Natal (RN) (SVL mean $=43.4, \mathrm{SD}=3.76 \mathrm{~mm}, N=$ seven males), ca. $1000 \mathrm{~km}$ northeast of our sites. Their data (first values within parentheses) are significantly different from ours in call duration (mean 4.03 vs. $5.90 \mathrm{~s} ; \mathrm{t}=2.779, d f=17, p=0.013)$ and in dominant frequency (mean 2906 vs. $2640 \mathrm{~Hz}$; = -5.289, $d f=17, p=0.000$ ). Protázio et al. (2015) reported on calls of specimens (SVL mean = $47.2, \mathrm{SD}=2.93 \mathrm{~mm}, N=$ three recorded males) from Cabaceiras, a Caatinga area in the state of 

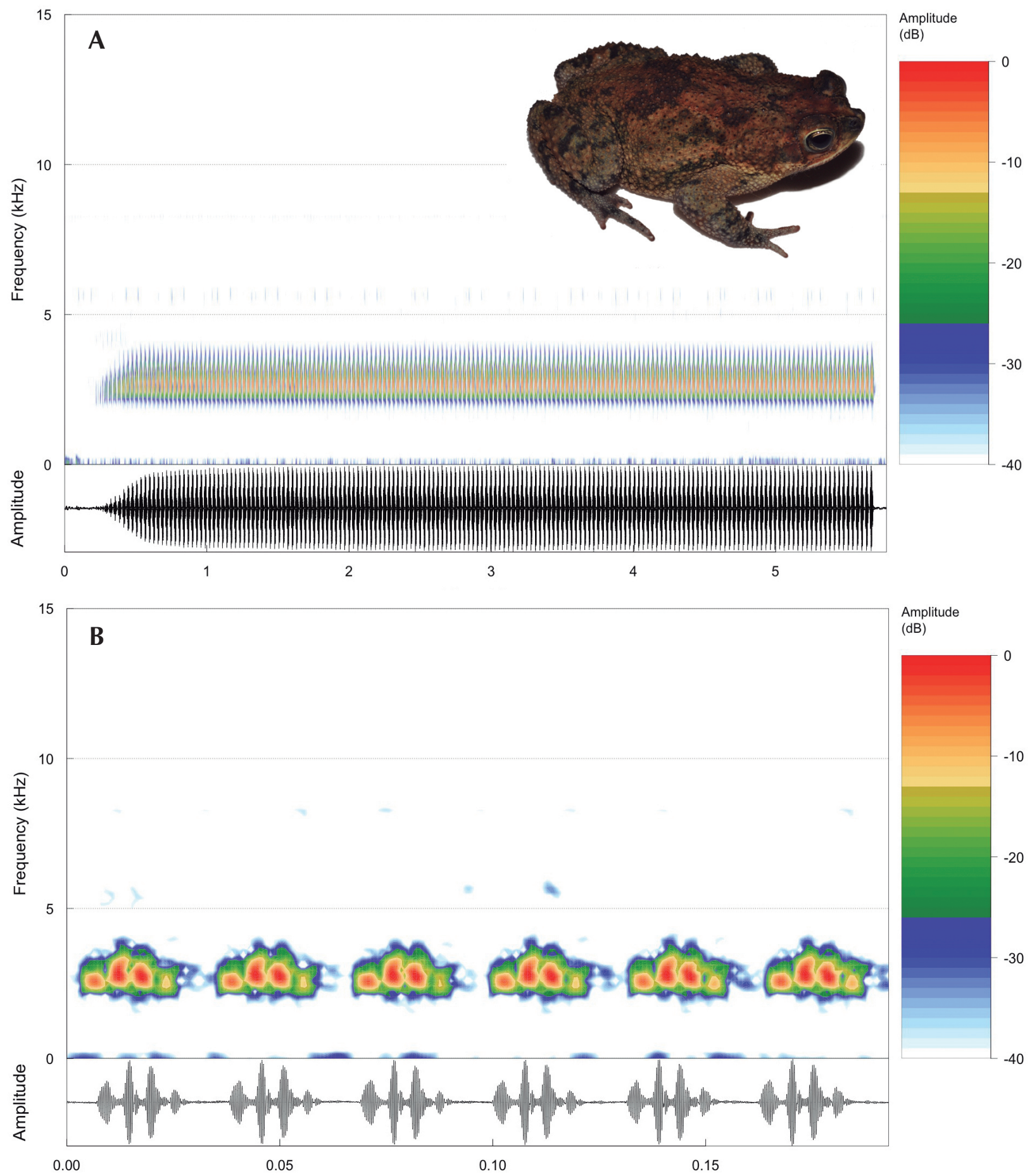

Figure 1. Spectrograms and respective oscillograms of the advertisement call of Rhinella granulosa from Andaraí, state of Bahia, Brazil. (A) A complete call (AndaraiBA5aAAGm671). (B) Six notes from the median portion of the call above illustrating pulses. Inset: an adult male (AAG-UFU 5610) from Caetité (Bahia state, Brazil). 


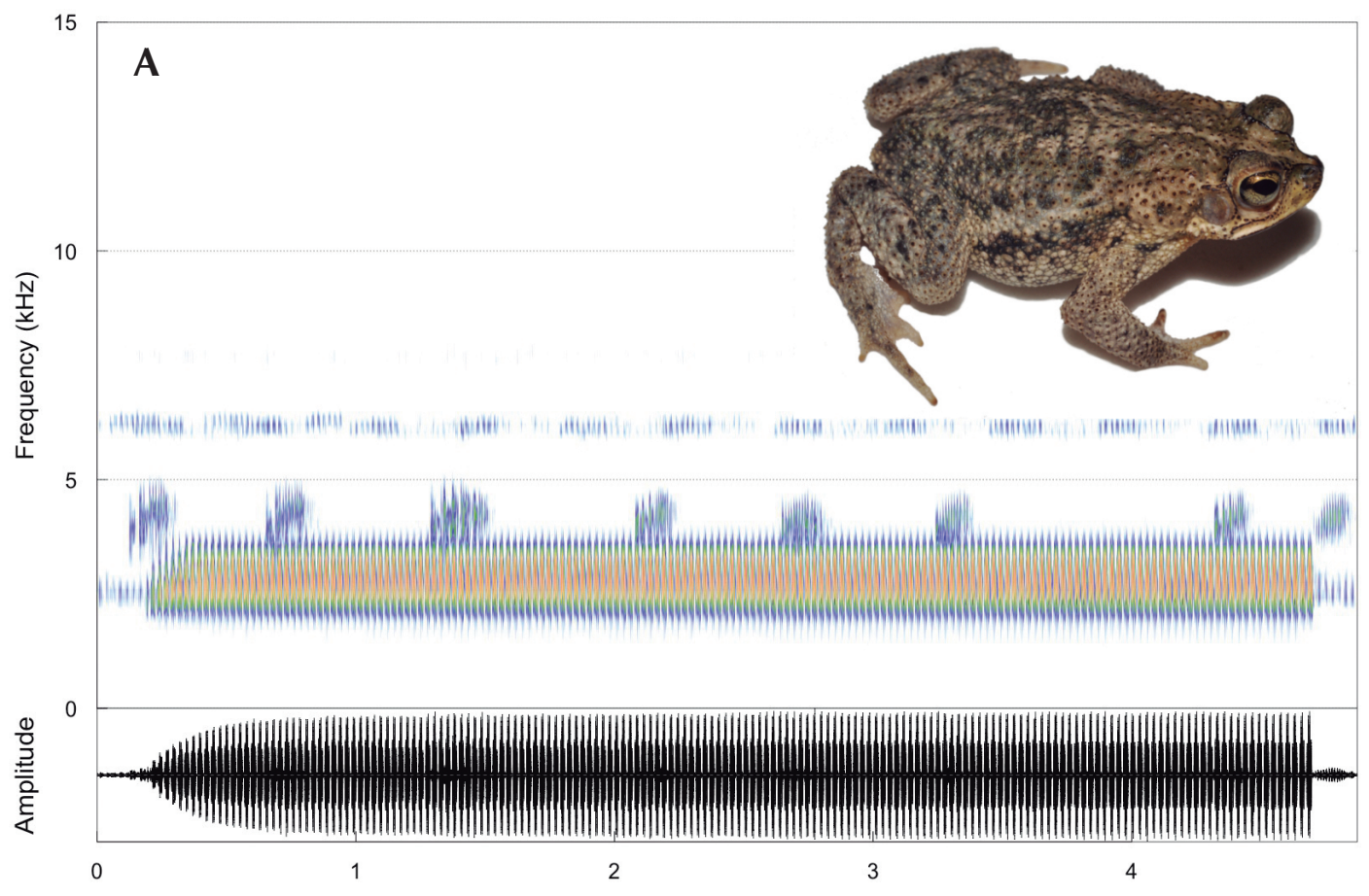

Amplitude
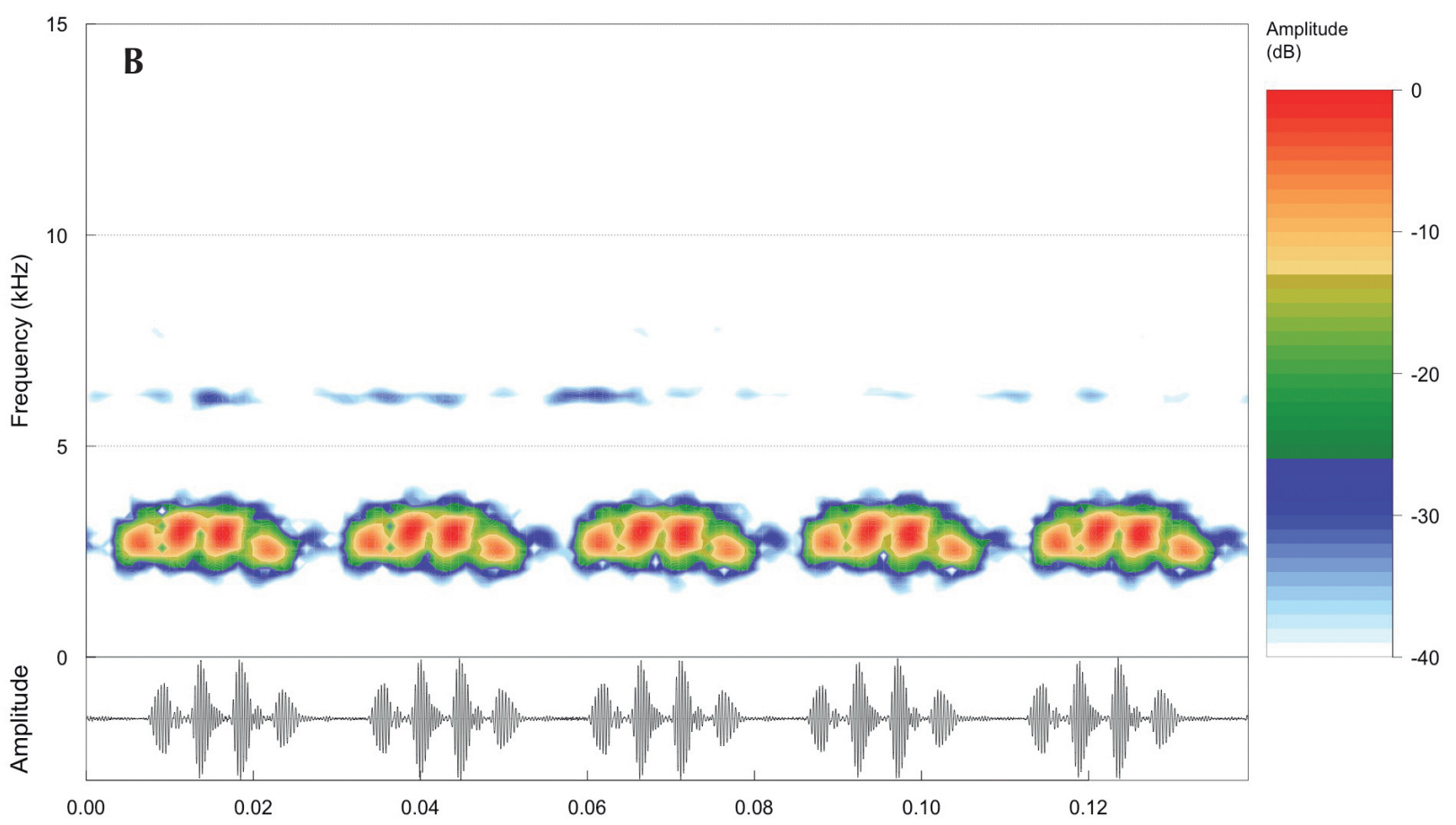

Figure 2. Spectrograms and respective oscillograms of the advertisement call of Rhinella merianae from Cantá, state of Roraima, Brazil. (A) A complete call (CantaRR2bAAGm671). (B) Five notes from the median portion of the call above illustrating pulses. Sound energy between $4-5 \mathrm{kHz}$ (in A) are due to Lysapsus laevis (Anura: Pseudinae) calls and that around $8 \mathrm{kHz}$ to a cricket. Inset: an adult male (call voucher AAG-UFU 5547) from Cantá (Roraima state, Brazil). 
Paraíba (PB). Their data are similar to those of São-Pedro et al. (2011) but are significantly different from ours in dominant frequency (mean $2949 \mathrm{~Hz} ; \mathrm{t}=-3.155, d f=13, p=0.008)$, but not in duration (0.67-6.80 vs. 3.7-9.6 ms). The slight differences in SVL between our sample and theirs may in part account for the lower dominant frequency we found because spectral traits are under morphological constraints, with smaller frogs producing calls with higher frequencies (Gerhardt and Huber 2002).

Our calls were recorded from interior localities of the state of Bahia, a region characterized by Caatinga (thorny vegetation), Atlantic Forest enclaves and human disturbed areas, while previous recordings from $R$. granulosa were from humid coastal (Atlantic Forest) and (arid) Caatinga (respectively), so it seems that present day climate is not a proximal factor promoting eventual populational isolation that could alternatively explain call differentiation, at least in dominant frequency. If call differences are not exclusively related to SVL, to random effects resulting from small sample sizes, and to clinal variation, features such as past climates and geographic barriers (e.g., relief and rivers) could have influenced population isolation/differentiation. Our samples are related to areas of the Espinhaço range (Chapada Diamantina) and are from south of the São Francisco River and its sand dunes, both regions known to harbor genetically differentiated animal populations in relation to those from the north (Oliveira et al. 2015, 2018). Therefore, our findings encourage further phylogeographic studies in order to elucidate the nature of the call differences found.

Regarding our data, $R$. granulosa differed from $R$. merianae in relation to inter-note interval (Wilcox Test, $\mathrm{Z}=2.79, p=0.003$ ), note duration $(\mathrm{Z}=2.58, p=0.009)$, and dominant frequency ( $\mathrm{Z}=-3.16, p=0.000)$. Our sample of $R$. granulosa differed from those of $R$. pygmaea (Carvalho et al. 2013, $N=2$ males), $R$. azarai (Guerra et al. 2011, $N=2$ males), $R$. fernandezae (Salas et al. 1998, $N=12$ males), and $R$. dorbignyi (Guerra et al. 2011, $N=13$ males) by having a modal number of four pulses (three in those species); $R$. bergi (Guerra et al. 2011, $N=$ 3 males) has two and $R$. major (Köhler et al. 1997, $N=1$ male; Guerra et al. 2011, $N=4$ males; Bernardes et al. 2015, $N=4$ males) has from five to eight. Compared to $R$. mirandaribeiroi (Morais et al. 2012, $N=2$ males), our calls of $R$. granulosa can be distinguished by note duration ( 33 vs. $21 \mathrm{~ms} ; \mathrm{t}=$ -7.476, $d f=12, p=0.000$ ) and dominant frequency ( 2463 vs. $2640 \mathrm{~Hz} ; \mathrm{t}=2.127, d f=12$, $p=0.05$ ). Compared to $R$. humboldti (TorresSuárez and Vargas-Salinas 2013, $N=6$ males), our calls for $R$. granulosa can be distinguished by call duration $(2.19$ vs. $5.9 \mathrm{~s}, \mathrm{t}=4.231, d f=$ $16, p=0.001)$, number of notes per call (100 vs. $187, \mathrm{t}=3.928, d f=16, p=0.001)$, and dominant frequency $(3153$ vs. $2640 \mathrm{~Hz} ; \mathrm{t}=-7.792, d f=16$, $p=0.000)$. In a brief account considering calls, Murphy et al. (2017) reported a call composed of three-pulsed notes attributed to $R$. beebei $(N=$ 1 male) with a frequency of $2750 \mathrm{~Hz}$ and a call with four pulsed notes attributed to $R$. humboldti ( $N=2$ males) with peak frequencies ranging between 2815 and $3150 \mathrm{~Hz}$. Considering such a simple description, this call of $R$. humboldti cannot be differentiated from that of $R$. granulosa. Rhinella granulosa calls also could not be distinguished from those of $R$. centralis (Zweifel 1965, $N=2$ males; Guerra et al. 2011, $N=1$ male) in any analyzed trait.

\section{Rhinella merianae}

The type locality of Rhinella merianae is not precisely defined but is stated as in "head falls of Essequebo River, Guiana" (Frost 2018). Its call is known from a single male from Silves (AM) at the margins of the Amazon River in Brazil (Guerra et al. 2011). The calls we report herein were recorded closer to the type locality $(\leq 250$ $\mathrm{km}$ northeast), a locality also within the Giana Shield, a region expected to harbor endemic biotic elements (Carvalho and Carvalho 2012). Comparisons with our data regarding $R$. 
granulosa were discussed above. Even though sample sizes precluded statistical tests, our data appear to differ from those of Guerra et al. (2011) in dominant frequency (2315 vs. 3036 $\mathrm{Hz}$ ). Considering also that both samples likely came from specimens living in very different habitats (forest vs. lavrado [savanna]), such differences indicate the need for further taxonomic investigation (e.g., morphology and genetic distances) on the specific status of the Amazon River bank population. Hoogmoed and Gorzula (1979) also refer to this species as a primarily open area dweller in southeastern Venezuela.

The call of Rhinella merianae, which has four pulses, can be distinguished from that of $R$. pygmaea (Carvalho et al. 2013), R. azarai (Guerra et al. 2011), R. fernandezae (Salas et al. 1998), and R. dorbignyi (Guerra et al. 2011), all of which have three pulses; $R$. bergi (Guerra et $a l$. 2011) has two pulses and $R$. major (Köhler et al. 1997, Guerra et al. 2011, Bernardes et al. 2015) has five to eight pulses. Considering data from the literature, $R$. merianae differs from $R$. granulosa by the number of notes per call both in São-Pedro et al. (2011) (149 vs. $193, \mathrm{t}=2.98$, $d f=10, p=0.014)$ and in Protázio et al. (2015) (132, $\mathrm{t}=2.51, d f=10, p=0.031)$. Rhinella merianae differs from $R$. mirandaribeiroi (Morais et al. 2012) by the note duration (33 vs. $19 \mathrm{~ms}, \mathrm{t}=-10.38, d f=5, p=0.000)$ and dominant frequency ( 2463 vs. $3036 \mathrm{~Hz} ; \mathrm{t}=10.97, d f=4$, $p=0.000$ ); from $R$. humboldti (Torres-Suárez and Vargas-Salinas 2013) by call duration (2.2 vs. $5.4 \mathrm{~s}, \mathrm{t}=3.37, d f=9, p=0.008)$, number of notes per call $(100$ vs. $193, \mathrm{t}=5.45, d f=9, p=$ $0.000)$ and note duration (22 vs. $19 \mathrm{~ms} ; \mathrm{t}=$ -4.954, $d f=9, p=0.001)$. Murphy et al. (2017, $N=1)$ reported three-pulsed notes for $R$. humboldti, a feature observed in some notes of a male of $R$. merianae. Murphy et al. (2017) reported four-pulsed notes for $R$. beebei $(N=2$ males) with ("mean") frequency between 2815 and $3150 \mathrm{~Hz}$; considering such a simple description, this call cannot be differentiated from that of $R$. merianae. From $R$. centralis
(Zweifel 1965, Guerra et al. 2011; both with $N=$ 1 male), $R$. merianae can apparently be distinguished by note intervals ( 9 vs. $7 \mathrm{~ms}$ ) and dominant frequency $(2541$ vs. $3036 \mathrm{~Hz})$. Zimmerman (1983) reported on a call of Rhinella granulosa (25.4 mm SVL) from around Manaus (Amazonas state, Brazil) with dominant frequency of $2100 \mathrm{~Hz}$. Considering the distribution map of Narvaes and Rodrigues (2009), Torres-Suárez and Vargas-Salinas (2013) attributed this call to $R$. merianae, which, according to our findings here, seems unlikely.

In summary, the differences we found in call data of $R$. granulosa and $R$. merianae indicate that further taxonomic investigations within an integrative approach (including data such as genetic distances) are needed to reevaluate the taxonomic status of some populations across their geographical distributions.

\section{Acknowledgments}

We thank B. F. V. Teixeira for his field assistance. Janalee P. Caldwell reviewed the English language. Cyro S. Bernardes made available his records. Two anonymous reviewers improved the draft. São Paulo Research Foundation (FAPESP) provided a doctoral fellowship to FSA (\#2015/10728-7). Collection permit was issued by ICMBio/SISBIO (300597). Financial support was given to the AAG team by CNPq (\#446935/2014-0 and \#152548/20114) and FAPEMIG (\#APQ-01724-14). A fellowship by $\mathrm{CNPq}$ was awarded to AAG (\#305261/2010-0). The Bioacoustics Research Program of the Cornell University provided licenses for Raven.

\section{References}

Barbosa, R. I., C. Campos, F. Pinto, and P. M. Fearnside. 2007. The "lavrados" of Roraima: Biodiversity and conservation of Brazil's Amazonian savannas. Functional Ecosystems and Communities 1: 29-41. 
Bernardes, C. S., T. R. Carvalho, and A. A. Giaretta. 2015. Advertisement call of Rhinella major (Anura: Bufonidae) from the lower Amazonas River basin with comments of intraspecific variation. Zootaxa 4012: 375-378.

Bioacoustics Research Program. 2014. Raven Pro: Interactive Sound Analysis Software (Computer software). Version 1.5. The Cornell Lab of Ornithology, Ithaca, New York. URL: http://www.birds.cornell.edu/raven.

Carvalho, T. M. and C. M. Carvalho. 2012. Interrelation of geomorphology and fauna of Lavrado region in Roraima, Brazil - suggestions for future studies. Quaternary Science Journal 61: 146-155.

Carvalho, T. R., V. C. M. Tolentino, and A. A. Giaretta. 2013. Advertisement call of Rhinella pygmaea (Myers and Carvalho, 1952) (Anura: Bufonidae) from the northern State of Rio de Janeiro. Herpetology Notes 6: 229-231.

Frost, D. R. 2018. Amphibian Species of the World: an Online Reference. Version 6.0 (29 Sep 2018). Eletronic Database accessible at http://research.amnh.org/ herpetology/amphibia/index.html. American Museum of Natural History, New York (USA). Captured on 29 September 2018.

Gerbing, D. W. 2018. lessR: Less Code, More Results. R package version 3.7.4. URL: https://cran.r-project.org/ web/packages/lessR/index.html.

Gerhardt, H. C. and F. Huber. 2002. Acoustic Communication in Insects and Frogs: Common Problems and Diverse Solutions. Chicago. University of Chicago Press. 542 pp.

Guerra, C., D. Baldo, S. Rosset, C. Borteiro, and F. Kolenc. 2011. Advertisement and release calls in Neotropical toads of the Rhinella granulosa group and evidence of natural hybridization between $R$. bergi and $R$. major (Anura, Bufonidae). Zootaxa 3092: 26-42.

Hoogmoed, M. S. and S. J. Gorzula. 1979. Checklist of the savanna inhabiting frogs of the El Manteco region with notes on their ecology and the description of a new species of treefrog (Hylidae, Anura). Zoologische Mededelingen 54: 183-216.

Hothorn, T., K. Hornik, M. A. Van de Wiel, and A. Zeileis. 2008. Implementing a class of permutation tests: the coin package. Journal of Statistical Software 28: 1-14.

Köhler, J., M. Jansen, A. Rodríguez, P. J. R. Kok, L. F. Toledo, M. Emmrich, F. Glaw, C. F. B. Haddad, M. O. Rödel, and M. Vences. 2017. The use of bioacoustics in anuran taxonomy: theory, terminology, methods and recommendations for best practice. Zootaxa 4251: 1-124.

Köhler, J., S. Reichle, and G. P. Bonn. 1997. Advertisement call of three species of Bufo (Amphibia: Anura: Bufonidae) from lowland Bolivia. Stuttgarter Beiträge zur Naturkunde 562: 1-8.

Murphy, J. C., T. Angarita-Sierra, J. R. Downie, and M. J. Jowers. 2017. Toads, tall mountains and taxonomy: the Rhinellagranulosa group(Amphibia: Anura: Bufonidae) on both sides of the Andes. Salamandra 53: 267-278.

Morais, A. R., R. P. Bastos, B. B. Annunziata, M. N. C Kokubum, and N. M. Maciel. 2012. Description of the advertisement call of Rhinella mirandaribeiroi (Gallardo, 1965) (Anura: Bufonidae). Zootaxa 3265: 66-68.

Narvaes, P. and M. T. Rodrigues. 2009. Taxonomic revision of Rhinella granulosa species group (Amphibia, Anura, Bufonidae), with a description of a new species. Arquivos de Zoologia, São Paulo 40: 1-73.

Oliveira, E. F., M. Gehara, V. A. SãoロPedro, X. Chen, E. A. Myers, F. T. Burbrink, D. O. Mesquita, A. A. Garda, G. R. Colli, M. T. Rodrigues, F. J. Arias, H. Zaher, R. M. L. Santos, and G. C. Costa. 2015. Speciation with gene flow in whiptail lizards from a Neotropical xeric biome. Molecular Ecology 24: 5957-5975.

Oliveira, E. F., P. A. Martinez, V. A. São-Pedro, M. Gehara, F. T. Burbrink, D. O. Mesquita, A. A. Garda, G. R. Colli, and G. C. Costa. 2018. Climatic suitability, isolation by distance and river resistance explain genetic variation in a Brazilian whiptail lizard. Heredity 120: $251-265$.

Pereyra, M. O., D. Baldo, B. L. Blotto, P. P. Iglesias, M. T. C. Thomé, C. F. B. Haddad, C. Barrio-Amorós, R. Ibáñez, and J. Faivovich. 2015. Phylogenetic relationships of toads of the Rhinella granulosa group (Anura: Bufonidae): a molecular perspective with comments on hybridization and introgression. Cladistics 2015: 1-18.

Protázio, A. S., R. L. Albuquerque, L. M. Falkenberg, and D. O. Mesquita. 2015. Acoustic ecology of an anuran assemblage in the arid Caatinga of northeastern Brazil. Journal of Natural History 49: 957-976.

R Core Team. 2018. R: A Language and Environment for Statistical Computing. R Foundation for Statistical Computing, Vienna, Austria. Version 3.4.1. URL https:// www.R-project.org/.

Salas, N. E., M. V. Zavattieri, I. E. Di Tada, A. L. Martino, and M. E. Bridarolli. 1998. Bioacoustical and ethoecological features in amphibian communities of Southern Córdoba Province (Argentina). Cuadernos de Herpetología 12: 37-46.

São-Pedro, V. A., P. H. Medeiros, and A. A. Garda. 2011. The advertisement call of Rhinella granulosa (Anura, Bufonidae). Zootaxa 3092: 60-62. 
Sueur, J., T. Aubin, and C. Simonis. 2008. Seewave, a free modular tool for sound analysis and synthesis. Bioacoustics 18: 213-226.

Torres-Suárez, O. L and F. Vargas-Salinas. 2013. The advertisement call of the toad Rhinella humboldti (Bufonidae). Zootaxa 3702: 198-200.
Zimmerman, B. L. 1983. A comparison of structural features of calls of open and forest habitat frog species in the Central Amazon. Herpetologica 39: 235-246.

Zweifel, R. G. 1965. Distribution and mating calls of the Panamanian toads, Bufo coccifer and B. granulosus. Copeia 1965: 108-110.

Editor: Ulisses Caramaschi 


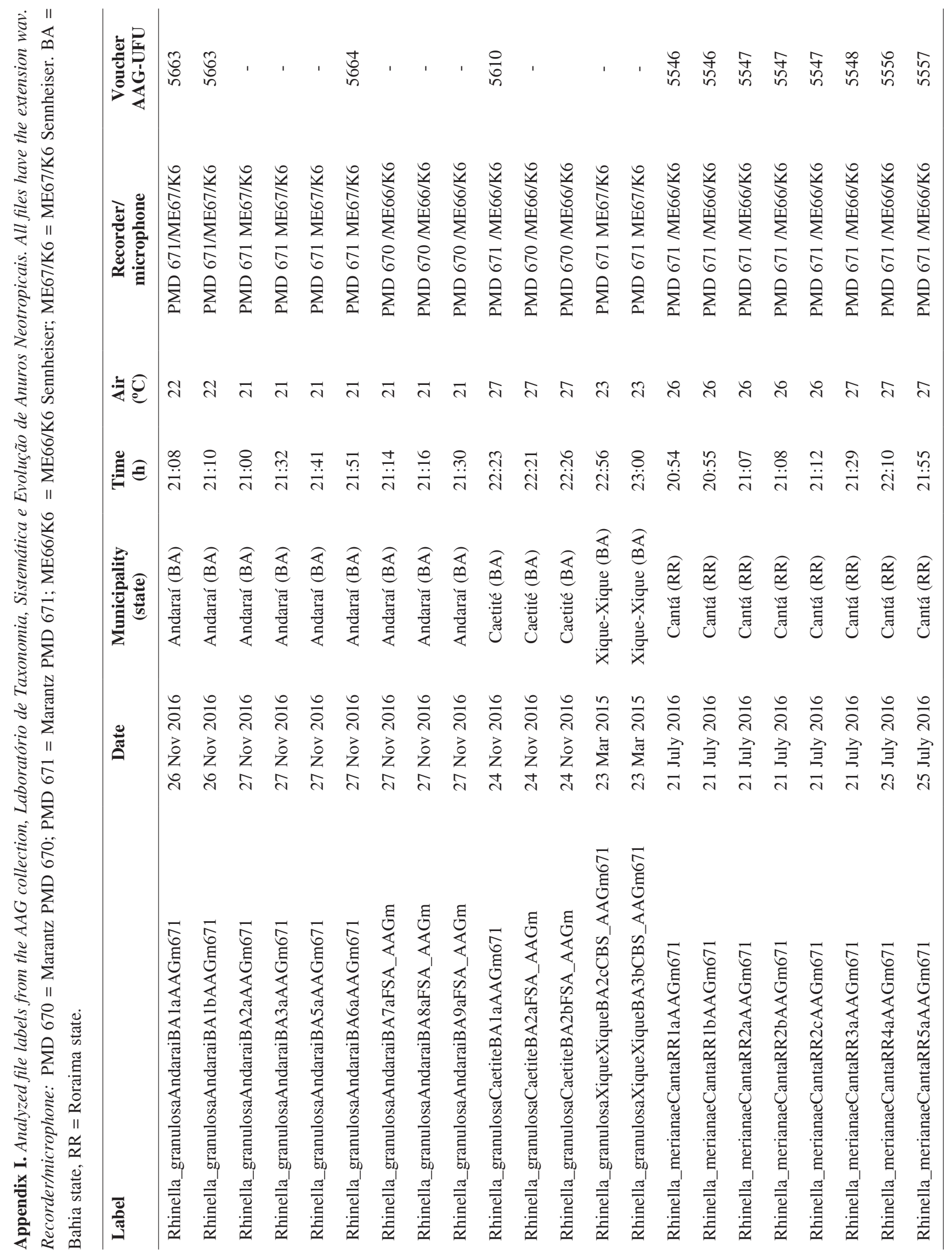

